DOI: $10.1515 /$ plass-2018-0007

Cristina Cantale ${ }^{1}$, Alessandro Belmonte ${ }^{1}$, Angelo Correnti ${ }^{1}$, Anna Farneti ${ }^{1}$, Fabio Felici ${ }^{1}$, Laura Gazza ${ }^{2}$, Arianna Latini ${ }^{1}$, Francesca Nocente ${ }^{2}$, Carla Micheli ${ }^{1}$, Francesco Petrazzuolo ${ }^{1}$, Patrizia Galeffi ${ }^{1}$

${ }^{1}$ ENEA Casaccia RC, via Anguillarese, 301 - 00123 Rome, IT, ${ }^{2}$ CREA-(QCE) Cereal Quality, via Manziana, 30 - 00189 Rome, IT

\title{
A MULTIDISCIPLINARY APPROACH TO CHARACTERIZE TRITICALE ELITE LINES FOR INDUSTRIAL USES
}

\begin{abstract}
Plant biomass and organic wastes from agriculture represent an effective resource to be exploited for a sustainable rural development, optimizing the land use, diversifying rural entrepreneurship, producing energy and new income.

Among crops, triticale is considered particularly interesting, showing several advantages such as high grain yield even in marginal environments, tolerance to drought, tolerance to more acid soils, lower production costs and lower susceptibility to biotic stresses.

In the frame of a long collaboration with CIMMYT (International Maize and Wheat Improvement Center$\mathrm{MX}$ ), eight triticale elite lines from Mexico were grown in Italy using marginal lands. An Italian triticale variety and a bread wheat line, specifically bred for bioenergy applications, were used for comparison. Over three growing seasons, different agronomic evaluations were obtained harvesting at milk phase. In the third growing season, a set of parcels was harvested also at maturity, to evaluate grain yields and quality parameters from seeds.

Milk phase biomass were properly dried and characterized following reference procedures, then used as substrate for anaerobic digestion to produce biogas and methane in lab-scale experiments.

Seeds from interesting lines were used to test different quality parameters including falling number in order to evaluate the fermentation ability. RAPD technique by two different panels of primers was used to genotype a selection of lines.
\end{abstract}

Key words: anaerobic digestion, biomass, energy, methane, triticale

\section{INTRODUCTION}

Triticale (X Triticosecale Wittmack) is a human-made crop, being a hybrid small grain produced crossing wheat and rye. Due to its genealogy, triticale

Communicated by Grzegorz Żurek 
combines traits as the rusticity, disease and environmental tolerance (including soil conditions), to high yield potential and good grain quality. Thus, it is particularly suited to give a new value to marginal environments currently dropped out of farming, in the frame of a sustainable rural development, able to optimize the land use and to transform wastes in effective resource for producing energy, diversifying rural entrepreneurship. As providing sustainable solutions to meet the world energy demand is a key challenge for the $21^{\text {st }}$ century (UNIDO, Advisory group on energy and climate change, 2010), the use of biomass as feedstock for anaerobic digestion opens new perspectives combining the different urgencies of energy needs, waste management and recycling and fertilizer requirement for agriculture.

In Italy, two varieties, Mizar and Rigel (released in 1979 and 1983 respectively), both constituted at ENEA, were the first national varieties to be registered. Both of them were characterized by high yields and high pest resistance and are still cultivated, even if newer varieties have been released, as a result of public or private investments. Given the current phase of market uncertainty, triticale represents an opportunity for the Italian entrepreneurs both for feed and bio-energy uses and innovative varieties are responding to these demands.

This study was aimed to evaluate and compare the yields and other parameters relevant for industrial applications in eight triticale elite lines constituted at CIMMYT (MX) and grown for the first time in Italy. For comparison, an Italian triticale variety, Magistral, and an Italian bread wheat variety, EW9, constituted as energy crop, were also included, as controls. These ten lines were grown over three seasons in different marginal areas relatively adjacent and harvested green biomasses were used to evaluate biogas potential. As harvesting time significantly affects the biogas yield (Amon et al., 2007; Mayer et al., 2014), plants were harvested at milk phase. Two batch experiments were carried out to evaluate biogas and methane potential.

Furthermore, a genetic approach was applied to evaluate the genetic variation in these lines. 15 RAPD markers were used to amplify DNAs and the resulting fingerprints were analysed.

\section{MATERIALS AND METHODS}

\section{Materials and Field Experiments}

Eight elite lines of triticale were provided from CIMMYT (MX). Field data collected at CENEB-CIMMYT (Obregon, MX) during their field experiments were also kindly provided. Triticale Magistral was kindly provided by Agrarian Faculty, University of Foggia, IT and bread wheat EW9 was provided by Società Produttori Sementi (Bologna, IT).

Italian field experiments were carried out during three crop seasons, 20102011, 2011-2012 and 2013-2014, in marginal areas close to Bracciano, Italy. In 2010-2011 season, trials were conducted in a marginal area near the Cupinoro dump $\left(42.0472^{\circ} \mathrm{N}, 12.1670^{\circ} \mathrm{E}\right.$, Bracciano Ambiente srl - Bracciano, IT). In another marginal area near Castel Giuliano $\left(42.0631^{\circ} \mathrm{N}, 12.1402^{\circ} \mathrm{E}\right.$, non-profit 
organization AaIS, Bracciano, IT) trials were conducted in 2011-2012 and 2013-2014 seasons. In 2013-2014 season trials were conducted using marginal area (out of area assigned to field trials) inside Casaccia Research Centre of ENEA $\left(42.0437^{\circ} \mathrm{N}, 12.3008^{\circ} \mathrm{E}\right.$, ENEA-Rome, IT). Experimental design always consisted of completely randomized rainfed fields with two replications. Soil were sampled to characterize composition and quality. Nitrogen $(100 \mathrm{~kg} / \mathrm{ha})$ was supplied always twice, at sowing and tillering phases.

Some agronomic traits were analysed during the seasons, at the phenological period ranging from booting to milk phase and at maturity. In 2010-2011, 20112012 and 2013-2014 (Casaccia+Castel Giuliano, partially) crop seasons, biomass was harvested at the milk-phase. Aerial part of plants were weighted, measured, sampled and then air-dried and stored, following Laboratory Analytical Procedures (Hames et al., 2008). Furthermore, in 2013-2014 season at Castel Giuliano, double plots were harvested at maturity. Grain yields and yield related traits were measured. Seeds were milled and quality parameter were also measured.

\section{Biomass and seed characterization}

The total solids (TS), volatile solids (VS), ash contents and other parameters of the fresh untreated and air-dried feedstock was determined by Laboratory Analytical Procedures (Sluiter et al., 2008; Sluiter et al., 2008a).

Thousand kernel weight (TKW) was calculated as the mean weight of 500 grains. Hectolitre weight reflects the density and the volume occupied by the grains; it was measured by a Shopper chondrometer equipped with a $1 \mathrm{~L}$ container and results are expressed as $\mathrm{kg} \mathrm{hL}-1$. Kernel hardness was determined by the Perten SKCS 4100 (Springfield, IL, USA) following the manufacturer's operating procedure. The instrument was set in a range of hardness values between -40 and +120 , and the SKCS index was recorded as the average of 300 kernels. The grains were ground with a laboratory mill (Cyclotec, Sweden) equipped with a $0.5 \mathrm{~mm}$ sieve prior to other analyses. Moisture content was analyzed with a thermos balance at $120^{\circ} \mathrm{C}$ (Sartorius, Germany). Protein content was determined by a Kjeldhal nitrogen analysis $(\mathrm{N}$ x 5.7) and was expressed as percentage on a dry weight basis (AACC N. 46.19.01). The falling number, that measures the $\alpha$-amylase enzyme in flour, was performed according to the standardized method (ICC N. 107/1 and AACC N. 56-81A) in a Perten Instrument on $7 \mathrm{~g}$ of flour and expressed in seconds. The storage protein pattern was analysed by SDS PAGE $10 \%$ electrophoresis standard procedure.

\section{Anaerobic digestion of biomass}

Anaerobic biogasification potential (ABP) was estimated by an anaerobic test in batch. The following protocol was used: $4.34 \mathrm{~g}$ dry matter, $262.5 \mathrm{~g}$ inoculum and $140 \mathrm{ml}$ distilled water were mixed in $500 \mathrm{ml}$ vials. Blanks consisted of same total weight (406.84 g) of inoculum. Anaerobic organisms used as inoculum came from an anaerobic digestion plant located at Nepi, Italy (Azienda Palombini) and met the following required analytical values: dry matter $<3 \%$, volatile fat acids (VFA) $<2000 \mathrm{mg}$ expressed as acetic acid/1 and N-NH4 $<3000 \mathrm{mg}$ 
expressed as N/l after adjustment. The vials were sealed with aluminium-faced gray rubber stoppers, purged by flowing argon in and out and put at $37^{\circ} \mathrm{C}$ in oven. For 75 days, the biogas production was evaluated by allowing gas to expand in a syringe and measuring the final volume; initially samples were collected daily, but frequency became infrequent with progressing of experiment. The composition of sampled volumes was analyzed by gas-chromatography (Dani DPC 1000, DANI Instruments spa, IT). Experiment was carried out in duplicate, including blanks.

The biochemical methane potential (BMP) was evaluated using an automatic methane potential test system (AMPTSII-Bioprocess Control Sweden AB). Vials containing samples and anaerobic inoculum (400 $\mathrm{g}$ of mixture, ratio of 2:1) were incubated at $37^{\circ} \mathrm{C}$ and mixed by a slow rotating agitator. Biogas continuously produced passed through an alkaline solution $(3 \mathrm{M} \mathrm{NaOH})$ to retain acid gas fractions (such $\mathrm{CO}_{2}$ and $\mathrm{H}_{2} \mathrm{~S}$ ) by chemical interaction, only allowing $\mathrm{CH}_{4}$ to pass through to the methane detector. Blanks containing just inoculums allowed to calculate inoculum contribute (background). Experiments were carried out in duplicate, including blanks. ABP and BMP were expressed per unit of volatile solids and values expressed for dry matter and wet matter were also derived using TS and VS content measured on another samples of same batch.

\section{Genotyping by RAPDs}

Some lines were genotyped by random amplified polymorphic DNA (RAPD). Genomic DNA was extracted from fresh leaves using the standard CTAB method (Murray and Thompson 1980). It was amplified by PCR (GeneAmp PCR system 2400, Applied Biosystems - Thermo Fisher Scientific Inc., Waltham, MA, USA) using the following 10 primers derived from sea and fossil grasses (Micheli et al. 2005): BY11 5'-ATCCACTGCA-3'; BY12 5'GGTCGCAGGC-3'; BY13 5'-CCTTGACGCA-3'; BY15 5'-CTCACCGTCC3'; DN4 5'-GTCGTGCTAT-3'; DN5 5'-CCGACGGCAA-3'; DN6 5'TGGACCGGTG-3'; UB24 5'-GGGTGAACCG-3'; UB26 5'-CGCCCCCAGT3' and UB28 5'-GCTGGGCCGA-3'. Amplification products were separated by gel-agarose $(1.4 \%)$, stained with ethidium bromide, analysed and images collected and by Gel Doc (Bio-Rad Laboratories Inc., Hercules, CA, USA). Experiments were carried out at least in duplicate. Additional five primers, described by Ashraf \& Ashraf (2015) as polymorphic in two bread wheat cultivars, were also used, following the same procedure. The analysis of molecular variance (AMOVA) was carried out using Arlequin Version 3.5.2.2 (Excoffier and Lischer, 2010) and the minimum haplotype spanning tree, computed from the matrix of pairwise distances calculated between all pairs of haplotypes, was displayed by Treeview (Page RDM, 1996).

\section{Data analysis}

Statistical analysis of data was carried out by R (version 3.4.0 extended via Agricolae package). The analysis of variance (ANOVA) for each parameter was performed at a $95 \%$ confidence level and the significance difference between 
means was tested by Tukey's method. Spearman correlation was evaluated to investigate factors influencing anaerobic digestion traits.

\section{RESULTS}

\section{Environmental features}

The three growing seasons showed quite different climate. The 2010-2011 season was characterized by a heavy rainfall, mainly on November $(294.4 \mathrm{~mm})$, December $(137 \mathrm{~mm})$, March $(165.4 \mathrm{~mm})$, an average temperature of $7.5^{\circ} \mathrm{C}$ and lowest average temperature of $4^{\circ} \mathrm{C}$, in winter. During the 2011-2012 season, the winter was relatively dry, with snow in February and abundant rainfall in spring (April $(91 \mathrm{~mm})$ and May $(133 \mathrm{~mm})$ ) and was characterized by an average temperature of $6.7^{\circ} \mathrm{C}$ and a minimum temperature average of $3.1^{\circ} \mathrm{C}$, in winter. The 2013-2014 season was characterized by abundant rainfall, on November (276 $\mathrm{mm})$ and from January $(282 \mathrm{~mm})$ to April $(115 \mathrm{~mm})$ and May $(107 \mathrm{~mm})$, being the average temperature $9.3^{\circ} \mathrm{C}$ and the minimum temperature average $5.9^{\circ} \mathrm{C}$, in winter.

Chemical analysis of soil

\begin{tabular}{lccc}
\hline \multicolumn{1}{c}{ Soil } & Cupinoro & Castel Giuliano & Casaccia \\
\hline Soil texture & sandy loam & sandy clay loam & sandy clay loam \\
pH & 6.3 & 7.3 & 6.3 \\
Organic matter & 3.08 & 1.59 & 2.51 \\
N tot \% & 0.17 & 0.1 & 0.15 \\
CEC \% & 16.63 & 17.47 & 26.3 \\
P ppm & 3 & 22 & 10 \\
Ca ppm & 1900 & 2400 & 2900 \\
Fe ppm & 54.2 & 22 & 52.4 \\
Mn ppm & 8.2 & 6 & 27.2 \\
Zn ppm & 1.6 & 4.6 & 5.4 \\
Na ppm & 94 & 159 & 117 \\
Mg/K sqm/sqm & 1 & 4.1 & 2.4 \\
\hline
\end{tabular}

In Fig. 1, a detailed diagram is shown. The chemical analyses of soils showed comparably values (see Table 1), compatible with marginal soils, Castel Giuliano resulting the poorest, in total organic matter and available nitrogen, and heavy, due to the presence of clay. Casaccia showed generally intermediate values, the highest cation exchange capacity and a very high concentration of manganese ion. 

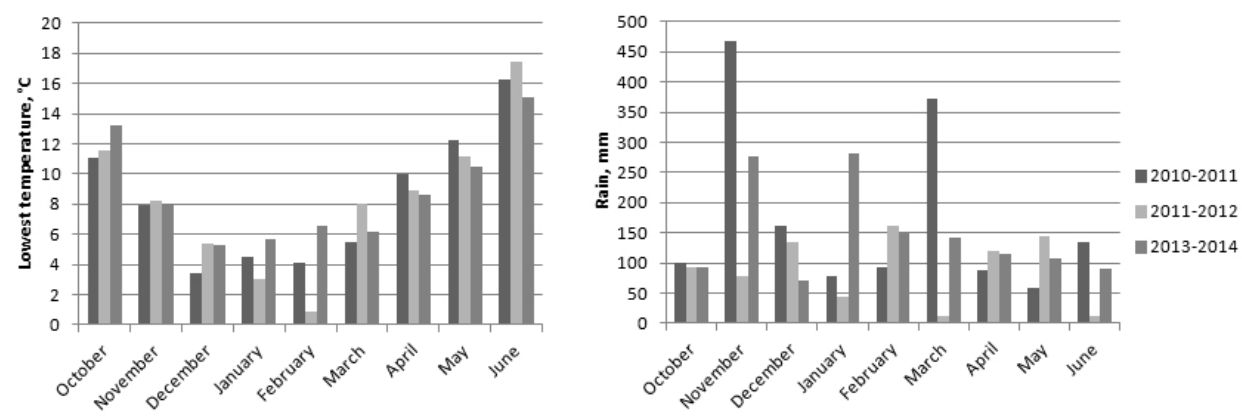

Fig. 1. The lowest temperature and the monthly rainfall measured during the three growing seasons

Field data and agronomic trait evaluation

Averaged traits from three year experiments carried out in Mexico

\begin{tabular}{ccccccccc}
\hline \multirow{2}{*}{ Line } & \multicolumn{3}{c}{ FULL IRRIGATION } & \multicolumn{4}{c}{ REDUCED IRRIGATION } \\
\cline { 2 - 9 } & $\begin{array}{c}\text { PHT } \\
{[\mathrm{cm}]}\end{array}$ & $\begin{array}{c}\text { GY } \\
{[\mathrm{t} / \mathrm{ha}]}\end{array}$ & $\begin{array}{c}\text { TWT } \\
{[\mathrm{kg} / \mathrm{hl}]}\end{array}$ & $\begin{array}{c}\text { TKW } \\
{[\mathrm{g}]}\end{array}$ & $\begin{array}{c}\text { PHT } \\
{[\mathrm{cm}]}\end{array}$ & $\begin{array}{c}\text { GY } \\
{[\mathrm{t} / \mathrm{h}]}\end{array}$ & $\begin{array}{c}\text { TWT } \\
{[\mathrm{kg} / \mathrm{hl}]}\end{array}$ & $\begin{array}{c}\text { TKW } \\
{[\mathrm{g}]}\end{array}$ \\
\hline 1 & 123 & 7.34 & 76.1 & 43.2 & 99 & 4.31 & 77.5 & 43.1 \\
2 & 116 & 7.25 & 75.7 & 46.6 & 99 & 4.34 & 75.4 & 42.8 \\
3 & 115 & 7.36 & 75.5 & 42.7 & 99 & 4.48 & 74.1 & 39.0 \\
4 & 124 & 7.55 & 77.1 & 49.4 & 105 & 3.98 & 77.6 & 42.8 \\
5 & 121 & 7.44 & 76.6 & 48.3 & 98 & 3.96 & 75.8 & 42.3 \\
6 & 108 & 7.49 & 72.1 & 57.4 & 88 & 4.11 & 72.5 & 43.7 \\
7 & 117 & 7.35 & 74.0 & 44.6 & 93 & 3.55 & 73.4 & 41.7 \\
8 & 120 & 7.49 & 73.8 & 42.0 & 90 & 3.44 & 72.1 & 33.8 \\
\hline
\end{tabular}

PHT=plant height; GY=grain yields; TWT=test weight; TKW=thousand kernel weight

Agronomic traits averaged over three seasons (2007-2009) in two environments (full and reduced irrigation) from experimental fields carried out in Obregon (MX) are reported in Table 2.

Data for physiological and agronomic traits from experiments carried out in Italy are reported in Table 3 (harvest at milk phase) and in Table 4 (harvest at maturity). It is worthwhile mentioning that 2013-2014 season was heavily affected by yellow rust, at different extension between the two locations, Casaccia being the most affected.

The comparison between Mexican and Italian data can be carried out comparing Table 2 and Table 4. Values measured in Italy resulted generally lower for plant height (PHT), test weight (TWT) and especially grain yields (GY), more comparable to those obtained in reduced irrigation in Mexico, and could be related to the combined effect of biotic (rust) and abiotic (poor soil-climate) stresses. Looking at data obtained from Italian fields (Table 3), PHT trait ap- 
peared significantly different among genotypes, independently from environment. Line 6 resulted shorter than the other CIMMYT lines in the three seasons and EW9 resulted always the shortest (due to the species specific differences, bread wheat versus triticale).

Table 3

Data from three year experiments carried out in Italy. Harvesting at milk phase

\begin{tabular}{|c|c|c|c|c|}
\hline \multirow{2}{*}{ Line } & $\begin{array}{l}2010-2011 \\
\text { Cupinoro. }\end{array}$ & $\begin{array}{c}\text { 2011-2012 } \\
\text { Castel Giuliano** }^{* *}\end{array}$ & $\begin{array}{c}2013-2014 \\
\text { Castel Giuliano** }\end{array}$ & $\begin{array}{c}\text { 2013-2014 } \\
\text { Casaccia**** }\end{array}$ \\
\hline & \multicolumn{4}{|c|}{$\mathrm{PTH}[\mathrm{cm}]$} \\
\hline 1 & $88.5^{\mathrm{ab}}$ & $96.0^{\mathrm{a}}$ & & $93^{c}$ \\
\hline 2 & $94.0^{\mathrm{a}}$ & $96.5^{\mathrm{a}}$ & $112^{\mathrm{a}}$ & $109^{a}$ \\
\hline 3 & $80.8^{\mathrm{abc}}$ & $94.5^{\mathrm{a}}$ & $95^{\mathrm{b}}$ & $82^{\mathrm{d}}$ \\
\hline 4 & $93.5^{\mathrm{a}}$ & $89.5^{\mathrm{ab}}$ & & $84^{d}$ \\
\hline 5 & $88.8^{\mathrm{ab}}$ & $96.0^{\mathrm{a}}$ & & $90^{c}$ \\
\hline 6 & $74.5^{\mathrm{bc}}$ & $80.0^{\mathrm{bc}}$ & & $74^{\mathrm{e}}$ \\
\hline 7 & $92.0^{\mathrm{ab}}$ & $96.0^{\mathrm{a}}$ & & $80^{d}$ \\
\hline 8 & $95.0^{\mathrm{a}}$ & $96.5^{\mathrm{a}}$ & & $90^{c}$ \\
\hline MAG & $97.8^{\mathrm{a}}$ & $97.5^{\mathrm{a}}$ & $113^{a}$ & $99.5^{b}$ \\
\hline EW9 & $68.3^{c}$ & $69.0^{\mathrm{c}}$ & $70^{c}$ & $60^{f}$ \\
\hline Line & \multicolumn{4}{|c|}{ DTH [days] } \\
\hline 1 & $106^{\mathrm{a}}$ & $152^{b}$ & $130^{\mathrm{de}}$ & $130^{\mathrm{cd}}$ \\
\hline 2 & $104^{\mathrm{a}}$ & $149^{b}$ & $126^{\mathrm{f}}$ & $125^{\mathrm{e}}$ \\
\hline 3 & $107^{\mathrm{a}}$ & $154^{\mathrm{ab}}$ & $134^{\mathrm{c}}$ & $130^{\mathrm{cd}}$ \\
\hline 4 & $99^{\mathrm{a}}$ & $150^{b}$ & $127^{\mathrm{ef}}$ & $128^{\mathrm{d}}$ \\
\hline 5 & $101^{\mathrm{a}}$ & $153^{b}$ & $142^{b}$ & $131^{\mathrm{cd}}$ \\
\hline 6 & $102^{\mathrm{a}}$ & $148^{b}$ & $126^{\mathrm{f}}$ & $128^{\mathrm{d}}$ \\
\hline 7 & $102^{\mathrm{a}}$ & $154^{\mathrm{ab}}$ & $131^{\mathrm{cd}}$ & $136^{\mathrm{b}}$ \\
\hline 8 & $101^{\mathrm{a}}$ & $150^{b}$ & - & $131^{\mathrm{c}}$ \\
\hline MAG & $105^{\mathrm{a}}$ & $154^{\mathrm{b}}$ & $170^{\mathrm{a}}$ & $140^{\mathrm{a}}$ \\
\hline EW9 & $104^{\mathrm{a}}$ & $160^{\mathrm{a}}$ & $144^{b}$ & $137^{\mathrm{ab}}$ \\
\hline Line & \multicolumn{4}{|c|}{ Spikes/Plants ratio } \\
\hline 1 & $4.7^{\mathrm{ab}}$ & $2.9^{b}$ & & $2.4^{\mathrm{a}}$ \\
\hline 2 & $4.8^{\mathrm{ab}}$ & $3.6^{\mathrm{a}}$ & & $3.1^{\mathrm{a}}$ \\
\hline 3 & $5.4^{\mathrm{ab}}$ & $3.4^{\mathrm{ab}}$ & & $2.2^{\mathrm{a}}$ \\
\hline 4 & $3.7^{\mathrm{abc}}$ & $3.0^{\mathrm{ab}}$ & & $1.9^{\mathrm{a}}$ \\
\hline 5 & $5.6^{\mathrm{a}}$ & $3.6^{\mathrm{ab}}$ & & $2.3^{\mathrm{a}}$ \\
\hline 6 & $5.2^{\mathrm{ab}}$ & $4.5^{\mathrm{ab}}$ & & $2.6^{\mathrm{a}}$ \\
\hline 7 & $3.3^{\mathrm{bc}}$ & $2.5^{\mathrm{ab}}$ & & $1.4^{\mathrm{a}}$ \\
\hline 8 & $3.4^{\mathrm{abc}}$ & $2.4^{\mathrm{ab}}$ & & $1.6^{\mathrm{a}}$ \\
\hline MAG & $1.5^{\mathrm{c}}$ & $2.7^{b}$ & & $2.4^{\mathrm{a}}$ \\
\hline EW9 & $3.4^{\mathrm{abc}}$ & $4.2^{\mathrm{b}}$ & & $2.6^{\mathrm{a}}$ \\
\hline
\end{tabular}




\begin{tabular}{|c|c|c|c|c|}
\hline \multirow{3}{*}{ Line } & \multicolumn{3}{|c|}{ Continued } & \\
\hline & $\begin{array}{l}2010-2011 \\
\text { Cupinoro. }\end{array}$ & $\begin{array}{c}\text { 2011-2012 } \\
\text { Castel Giuliano** }\end{array}$ & $\begin{array}{c}\text { 2013-2014 } \\
\text { Castel Giuliano** }\end{array}$ & $\begin{array}{c}2013-2014 \\
\text { Casaccia**** }\end{array}$ \\
\hline & \multicolumn{4}{|c|}{ Total Mass $[\mathrm{kg}]$} \\
\hline 1 & $4.3^{\text {cde }}$ & $4.24^{\mathrm{b}}$ & & $7.47^{\mathrm{bc}}$ \\
\hline 2 & $6.4^{\mathrm{bcd}}$ & $8.0^{\mathrm{a}}$ & & $12.04^{\mathrm{a}}$ \\
\hline 3 & $2.0^{\mathrm{e}}$ & $5.59^{\mathrm{ab}}$ & & $5.92^{\mathrm{bcd}}$ \\
\hline 4 & $4.6^{\text {cde }}$ & $5.4^{\mathrm{ab}}$ & & $4.94^{\mathrm{bcd}}$ \\
\hline 5 & $4.1^{\mathrm{cde}}$ & $5.0^{\mathrm{ab}}$ & & $7.49^{\mathrm{bc}}$ \\
\hline 6 & $2.1^{\mathrm{de}}$ & $5.54^{\mathrm{ab}}$ & & $5.32^{\mathrm{bcd}}$ \\
\hline 7 & $7.9^{\mathrm{bc}}$ & $5.82^{\mathrm{ab}}$ & & $3.92^{\mathrm{cd}}$ \\
\hline 8 & $7.2^{\mathrm{bc}}$ & $4.89^{\mathrm{ab}}$ & & $4.43^{\text {bcd }}$ \\
\hline MAG & $12.2^{\mathrm{a}}$ & $3.99^{\mathrm{b}}$ & & $7.54^{\mathrm{b}}$ \\
\hline EW9 & $10.2^{\mathrm{ab}}$ & $4.48^{\mathrm{b}}$ & & $2.45^{\mathrm{d}}$ \\
\hline
\end{tabular}

Lines 1-8 stands for CIMMYT elite lines; MAG stands for Magistral. PHT=plant height; DTH=days to heading; Total Mass refers to the total weight of biomass; significance codes: *** $\mathrm{P}<0.001,{ }^{*} \mathrm{P}<0.01, * \mathrm{P}<0.05$, . $\mathrm{P}<0.1$; means with the same letter are not significantly different

Table 4

Data from 2013-2014 trial carried out in Italy. Harvesting at maturity

\begin{tabular}{ccccc}
\hline \multirow{2}{*}{ LINE } & $\begin{array}{c}\text { PHT } \\
{[\mathrm{cm}]^{* * *}}\end{array}$ & $\begin{array}{c}\mathrm{GY} \\
{[\mathrm{ton} / \mathrm{ha}]}\end{array}$ & $\begin{array}{c}\text { TWT } \\
{[\mathrm{kg} / \mathrm{hL}]^{*}}\end{array}$ & $\begin{array}{c}\text { TKW } \\
{[\mathrm{g}]^{* * *}}\end{array}$ \\
\cline { 2 - 5 } & \multicolumn{5}{c}{$\begin{array}{c}2013-2014 \\
\text { Castel Giuliano }\end{array}$} \\
\hline 1 & $103^{\mathrm{bc}}$ & $2.87^{\mathrm{a}}$ & $71.6^{\mathrm{a}}$ & $54.0^{\mathrm{ab}}$ \\
2 & $115.5^{\mathrm{a}}$ & $2.52^{\mathrm{ab}}$ & $69.6^{\mathrm{ab}}$ & $52.1^{\mathrm{bc}}$ \\
3 & $95.5^{\mathrm{de}}$ & $2.78^{\mathrm{a}}$ & $68.1^{\mathrm{ab}}$ & $46.9^{\mathrm{e}}$ \\
4 & $91.5^{\mathrm{e}}$ & $2.78^{\mathrm{a}}$ & $70.7^{\mathrm{ab}}$ & $50.1^{\mathrm{cd}}$ \\
5 & $108^{\mathrm{b}}$ & $2.33^{\mathrm{ab}}$ & $68.6^{\mathrm{ab}}$ & $47.5^{\mathrm{de}}$ \\
6 & $85^{\mathrm{f}}$ & $1.67^{\mathrm{b}}$ & - & $56.2^{\mathrm{a}}$ \\
7 & $99^{\mathrm{cd}}$ & $2.8^{\mathrm{a}}$ & $67.2^{\mathrm{b}}$ & $50.9^{\mathrm{c}}$ \\
8 & - & - & - & - \\
MAG & $107.5^{\mathrm{b}}$ & $2.01^{\mathrm{b}}$ & $62.7^{\mathrm{c}}$ & $43.5^{\mathrm{f}}$ \\
EW9 & $71.5^{\mathrm{g}}$ & $1.93^{\mathrm{b}}$ & $72.0^{\mathrm{a}}$ & $46.15^{\text {ef }}$ \\
\hline
\end{tabular}

Significance codes: $* * * \mathrm{P}<0.001,{ }^{*} \mathrm{P}<0.05, . \mathrm{P}<0.1$; means with the same letter are not significantly different 
Climate affected heavily days-to-heading (DTH) trait: in 2011-2012, the effect of cold is clear in the delayed heading stage (on average 50 days in comparison with 2010-2011), but genotype effect was faintly significant inside and across seasons. Climate affected also spikes to plants ratio: both the late spring rain inducing second tillering in 2011-2012 and the yellow rust in 2013-2014 could be responsible for lower spike/plant ratio, in comparison with 2010-2011 season. Concerning total biomass production, genotype and genotype:year resulted the most significant source of variance $(p<0.001)$. In particular, performance of line 2 was significantly different from the others and showed a continuous increasing, suggesting an evident adaptation to the Italian clime and environment. Other lines showed an improvement between the first two seasons, followed by stabilization. On the contrary, lines 7 and 8, after initial exploit, declined in the following seasons. EW9 resulted extremely sensitive to rust and a full parcel was lost in Casaccia. No significant correlation was found among these traits (data not showed).

\section{Grain quality}

The technological quality of lines is reported in Table 5. ANOVA showed that humidity, protein and gluten values are just faintly different among lines, at very low level of significance, while SKCS hardness Index and the falling number values resulted highly genotype dependant (data not shown). Both last parameters are really important in view of applications based on fermentation, being related to the $\alpha$-amylase content. No significant correlation was found among them (data not shown).

\begin{tabular}{cccccc}
\multicolumn{5}{c}{ Technological quality } & Table 5 \\
\hline Line & $\begin{array}{c}\text { Moisture } \\
{[\% \mathrm{dm}]}\end{array}$ & Protein $[\% \mathrm{dm}]$ & Gluten $[\% \mathrm{dm}]$ & $\begin{array}{c}\text { SKCS } \\
\text { index *** }\end{array}$ & $\begin{array}{c}\text { Falling Number } \\
{[\mathrm{sec}]^{* *}}\end{array}$ \\
\hline 1 & $15.80^{\mathrm{a}}$ & $11.45^{\mathrm{a}}$ & $8.55^{\mathrm{abcd}}$ & $73.00^{\mathrm{bcd}}$ & $82.25^{\mathrm{c}}$ \\
2 & $17.35^{\mathrm{a}}$ & $11.50^{\mathrm{a}}$ & $8.10^{\mathrm{cd}}$ & $61.50^{\mathrm{d}}$ & $246.50^{\mathrm{a}}$ \\
3 & $17.50^{\mathrm{a}}$ & $11.60^{\mathrm{a}}$ & $8.15^{\mathrm{bcd}}$ & $64.00^{\mathrm{cd}}$ & $76.50^{\mathrm{c}}$ \\
4 & $16.62^{\mathrm{a}}$ & $10.95^{\mathrm{a}}$ & $8.05^{\mathrm{cd}}$ & $89.50^{\mathrm{a}}$ & $151.50^{\mathrm{b}}$ \\
5 & $17.65^{\mathrm{a}}$ & $11.50^{\mathrm{a}}$ & $8.65^{\mathrm{abcd}}$ & $63.50^{\mathrm{cd}}$ & $103.35^{\mathrm{bc}}$ \\
6 & $17.50^{\mathrm{a}}$ & $12.20^{\mathrm{a}}$ & $9.50^{\mathrm{ab}}$ & $81.00^{\mathrm{ab}}$ & $62.00^{\mathrm{c}}$ \\
\hline MAG & $16.90^{\mathrm{a}}$ & $13.15^{\mathrm{a}}$ & $9.39^{\mathrm{abc}}$ & $38.75^{\mathrm{e}}$ & $77.06^{\mathrm{c}}$ \\
EW9 & $17.40^{\mathrm{a}}$ & $10.95^{\mathrm{a}}$ & $7.80^{\mathrm{d}}$ & $75.50^{\mathrm{bc}}$ & $62.00^{\mathrm{c}}$ \\
\hline & $18.15^{\mathrm{a}}$ & $10.95^{\mathrm{a}}$ & $9.70^{\mathrm{a}}$ & $40.00^{\mathrm{e}}$ & $65.00^{\mathrm{c}}$ \\
\hline
\end{tabular}

dm stands for dry material; significance codes: $* * * \mathrm{P}<0.001, * * \mathrm{P}<0.01, . \mathrm{P}<0.1$; means with the same letter are not significantly different

The storage protein pattern was compared among the lines. An example of obtained result is shown in Fig. 2. Each line showed a specific pattern. 


\section{T1 T2 T7a T7b T7c T3a T3b T4a T4b T4c}

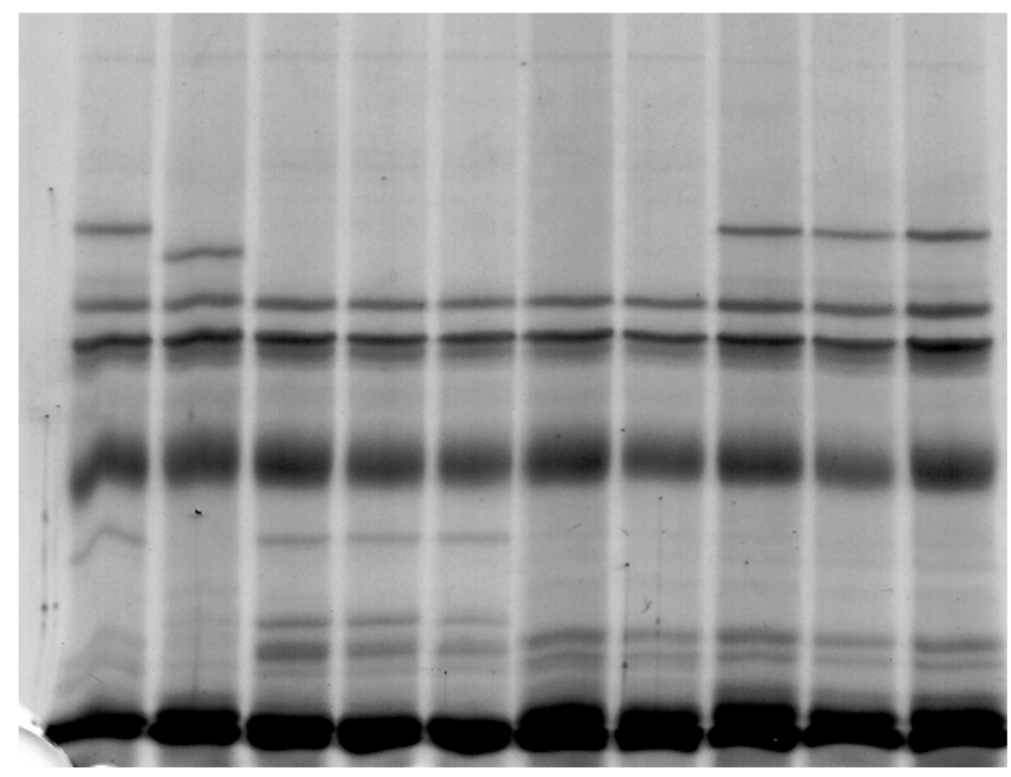

Fig. 2. Example of storage protein pattern from some triticale lines. Lines are indicated by $\mathrm{T}$ letter and genotype number, in case followed by a letter for the single seed protein extraction

\section{Anaerobic digestion of biomass}

Taking into account total mass and some preliminary results (Cantale et al., 2014), biomass from four lines (lines 2 and 3, Magistral and EW9) from two areas, Castel Giuliano and Casaccia (2013-2014 season) were used in a batch experiment to evaluate ABP. Furthermore, same four lines from Castel Giuliano and two lines from Casaccia (line 2 and EW9) were tested to evaluate BMP. Results are shown in Fig. 3. Considering the whole data, the average ABP was $369 \mathrm{~m}^{3} \times$ ton $^{-1}$ based on fresh weight (RSD: 5.6), $599 \mathrm{~m}^{3} \times$ ton $^{-1}$ based on VS (RSD: 4.18) and the biogas yield per hectare (the result of the product of $\mathrm{ABP}_{\mathrm{VS}}$ with biomass vs yield), spanned 3700-20600 $\mathrm{m}^{3} \times \mathrm{ha}^{-1}$. Also, the average BMP was $181 \mathrm{~m}^{3} /$ ton based on fresh weight (RSD: 14.67), $379 \mathrm{~m}^{3} /$ ton based on VS (RSD: 0.67) and the biomethane yield per hectare (the result of the product of BMP $_{\mathrm{VS}}$ with biomass vs yield), spanned $2500-12500 \mathrm{~m}^{3} \times \mathrm{ha}^{-1}$. VS content resulted significantly different $(p<0.001)$ among lines (data not shown). Significant differences in $\mathrm{ABP}_{\mathrm{VS}}$ values were not found for different lines and different environments, but $\mathrm{BMP}_{\mathrm{VS}}$ varied significantly $(p<0.001)$ within the environments, being values of lines grown in Casaccia lower than those grown in Castel Giuliano. Biogas yield per hectare was highly $(p<0.01)$ and positively correlated to biomass ${ }_{\mathrm{VS}}$ yield and $\mathrm{ABP}_{\mathrm{VS}}$. Similarly, biomethane yield per hectare 
was highly $(p<0.01)$ and positively correlated to biomass ${ }_{\mathrm{VS}}$ yield, but was not correlated to $\mathrm{BMP}_{\mathrm{VS}}$.
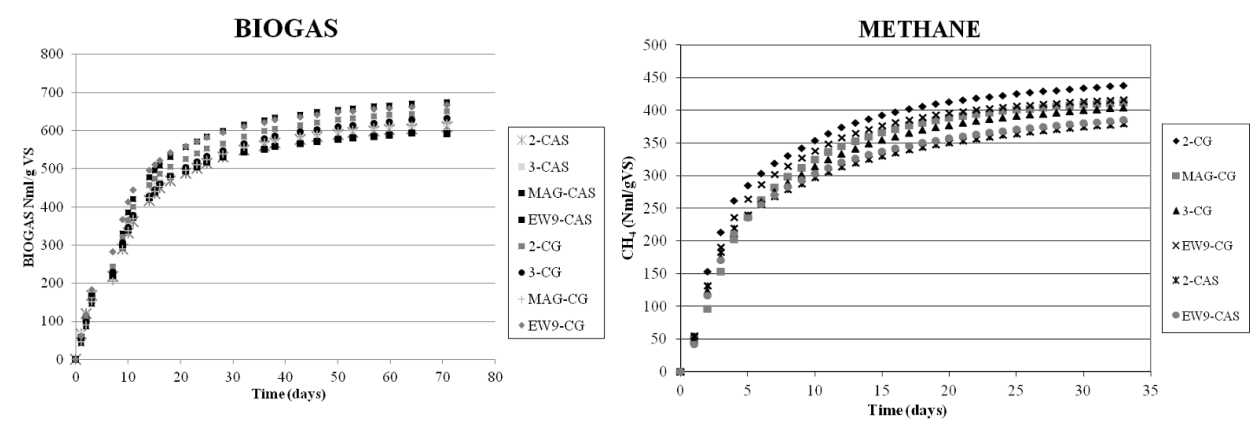

Fig. 3. Biogas and biomethane production of some lines during the fermentation experiments. Lines are indicated by their number plus field location: CAS stands for Casaccia and CG stands for Castel Giuliano

\section{Genotyping by RAPD}

The genetic variation among the six most interesting lines was evaluate using RAPD technique (Micheli et al., 2012). An example of obtained results is shown in Fig. 4. Fingerprints from 10 primers derived from sea and fossil grasses allowed to identify five haplotypes, lines 1 and 2 sharing the same fingerprint. Furthermore, they allowed to distinguish triticale from bread wheat lines (AMOVA among population, Fixation Index $F s t=0.597, \mathrm{p}<0.0001$ ). Considering the whole set of primers (15), it resulted that each genotype represented an haplotype and the variances among triticale and bread wheat decreased ( $F s t=0.336, p<0.0001$ ). The minimum spanning tree derived is shown in Fig. 5.

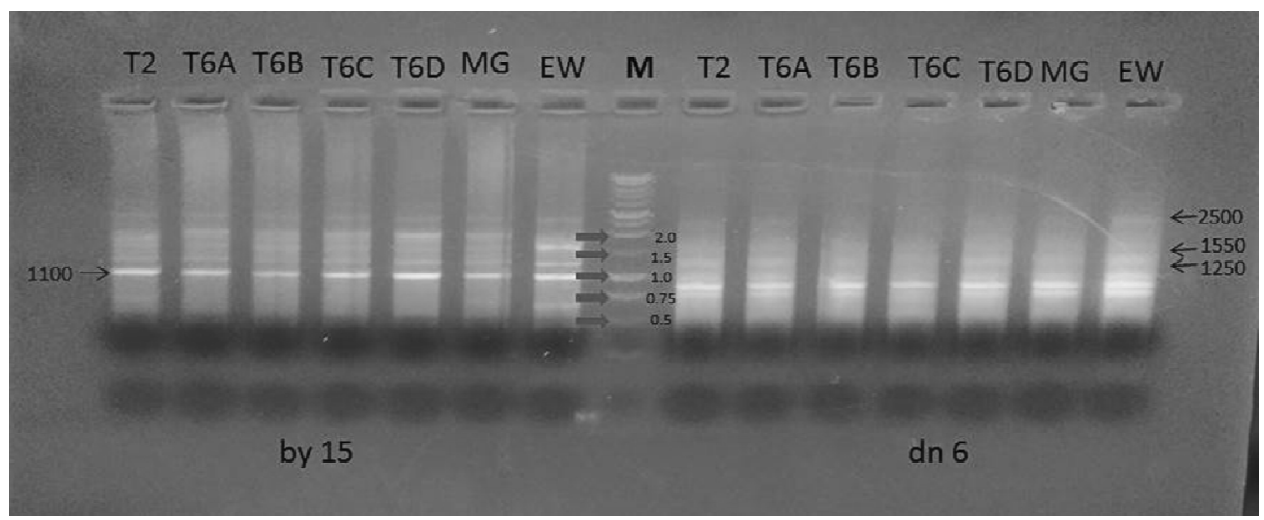

Fig. 4. Example of a RAPD amplification. BY15 and DN6 were the primers used for amplification. Lines are indicated by $\mathrm{T}$ letter and genotype number, in case followed by a letter for the preparation, MG stands for Magistral, EW stands for EW9. M stands for molecular marker 


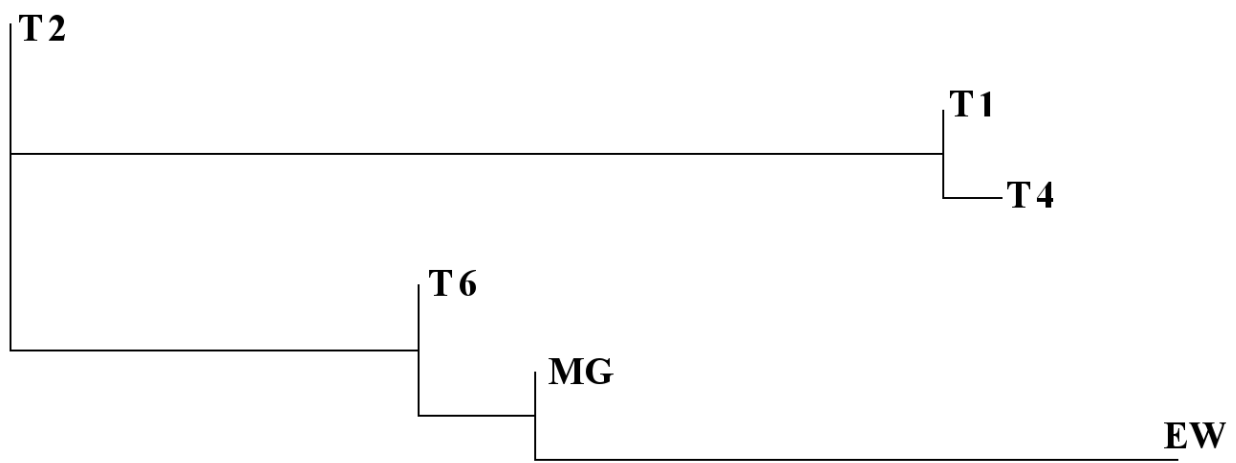

Fig. 5. Minimum spanning tree derived by the evaluation of molecular variability. Lines are indicated by $\mathrm{T}$ letter and genotype number, MG stands for Magistral, EW stands for EW9

\section{DISCUSSION AND CONCLUSIONS}

Environment affected heavily traits analysed in these triticale lines, as shown by a comparison with data from Mexico. Both marginal soils and weather events reduced performances, as well as the yellow rust plague in the 20132014 season. Initially, in the 2010-2011 season, the acclimated Italian lines, Magistral and EW9, led the challenge, but gradually genetics asserted its value and other lines emerged.

The traits measured in analysed lines appeared statistically different at various levels of significance, both considering seasons and genotypes.

Looking at the aim of this study, the total biomass production represents a critical trait in view of methane production. As an overall conclusion, the line 2 can be considered the most promising one, because its biomass remained quite high and nevertheless stable, showing a continuous increase. It is worth of noting, that the line 2 was considered at CIMMYT the most interesting of the whole group, information being available to us only after our analyses.

Concerning grain yields, that could be evaluated just in 2013-2014 season at Castel Giuliano location, values appear very lower in comparison with Mexico, even considering reducing irrigation. Surely, the use of marginal lands prevents high yields performances, nevertheless this issue has to be better investigated, as industrial applications are foreseen. The effect of the variety was highly significant on the quality parameters of SKCS hardness index $(\mathrm{P}<0.001)$ and FN $(<0.01)$. Both of them are relevant to fermentation. It has been found a strong correlation between low SCKS index, high diastatic power (a measure of how much starch-converting enzyme any given malt contains) and malt extract (Nagamine et al., 2009) in malting barley. Besides, FN is in relationship with the auto-amylolytic activity and is a major parameter, allowing to reduce the addition of enzymes for saccharification, saving costs. No significant correlation was found between these two parameters in this study. Overall results indicated line 1 and line 7 as very interesting and they will be used in future experi- 
ments for producing bio-ethanol (very-high-gravity fermentation protocol) and beer.

Biomasses were tested for biogas and biomethane potentials. Both ABP and BMP values are in agreement with literature data (Official Information Portal on Anaerobic Digestion at: http://www.biogas-info.co.uk/biogas-yields.html; Braun, 2007; Frigon and Guiot, 2010). No significant differences between ABP values was found among the lines, irrespective of environments, suggesting that the most influential factor controlling the biogas yield per hectare was the biomass yield, which in turn is controlled by genetics and environment. On the other hand, line 2 showed the highest BMP value and significant differences $(p<0.001)$ were found among environments, biomasses from Casaccia resulting less productive than those from Castel Giuliano. The effect of environment (soil and weather conditions) on BMP was previously observed in maize (Mayer et al., 2014) and can be directly related to the effect of the physiological state of crops on biomass composition (ergo digestibility) at harvest. Thus, soil composition associated with the heavier yellow rust infection observed for Casaccia fields could affect the biochemical composition of biomass, thus explaining lower BMP values (Murray et al., 1995).

Concerning genotyping by RAPDs, the used panel was able to discriminate the lines, allowing to identify different haplotypes. It resulted that the highest genetic variation is ascribed to differences among individuals within populations $(\mathrm{Fst}=0.664, \mathrm{p}<0.0001)$. Of course, these results are preliminary and a larger panel of primers applied to the whole set of triticale lines is planned to obtain a more complete scenario.

Triticale proves itself as a well adaptable crop, able to grow with good yields in marginal areas. Nevertheless, genetics plays its role and the analysed lines show differences in performances, suggesting that a specific choice of the line is able to affect the success of its industrial use.

\section{ACKNOWLEDGMENT}

The authors are really grateful to Dr. Vito Pignatelli for his support to this project.

The authors wish to thank Dr. K. Ammar (CIMMYT), Dr. A. Massi (ProSementi-Bologna_Syngenta, IT) and G. Basso (Faculty of Agricultural Sciences, Foggia University, IT) for providing seeds of 8 triticale elite lines, EW9 and Magistral, respectively and Dr. Giulio Marconi (ENEA library service) for his constant assistance. The authors wish to thank the non-profit organization AaIS, Bracciano-IT for providing field areas and labouring.

\section{REFERENCES}

Amon T, Amon B, Kryvoruchko V, Machmuller A, Hopfner-Sixt K, Bodiroza V, Hrbek R, Friedel J, Potsch E, Wagentristl H, Schreiner M, Zollitsch W (2007) Methane production through anaerobic digestion of various energy crops grown in sustainable crop rotations. Bioresource Technology 98, 3204-3212 
Ashraf MA and Ashraf M (2015) Growth stage-based modulation in physiological and biochemical attributes of two genetically diverse wheat (Triticum aestivum L.) cultivars grown in salinized hydroponic culture. Environ Sci Pollut Res DOI 10.1007/s11356-015-5840-5

Braun R (2007) Anaerobic digestion - A multi faceted process for energy, environmental management and rural deve-lopment. In: Improvement of crop plants for industrial end users. Ranalli P Editor. Publisher, Springer pp 335-416

Cantale C, Correnti A, Farneti A, Felici F, Mentuccia L, Pignatelli V, Sprocati AR, Ammar K, Galeffi P (2014) Evaluation of triticale as energy crop in Italy. Commun Agric Appl Biol Sci 79(4):211-5.

Excoffier L, Lischer HEL (2010) Arlequin suite ver 3.5: A new series of programs to perform population genetics analyses under Linux and Windows. Molecular Ecology Resources 10: 564-567

Frigon JC and Guiot SR (2010) Biomethane production from starch and lignocellulosic crops: a comparative review. Biofuels, Bioprod Bioref 4:447-458

Hames B, Ruiz R, Scarlata C, Sluiter A, Sluiter J, Templeton D (2008) Preparation of Samples for Compositional Analysis. National Renewable Research Laboratory Technical Report NREL/TP-510-42620

Mayer F, Gerin PA, Noo A, Foucart G, Flammang J, Lemaigre S, Sinnaeve G, Dardenne P, Delfosse P (2014) Assessment of factors influencing the biomethane yield of maize silages. Bioresource Technology 153:260-268

Micheli C, Paganin P, Peirano A, Caye G, Meinesz A, Bianchi CN (2005) Genetic variability of Posidonia oceanica (L) Delile in relation to local factors and biogeographic patterns. Aquatic Botany 82:210-223

Micheli C, Cupido R, Lombardi C, Belmonte A, Peirano A (2012) Changes in Genetic Structure of Posidonia oceanica at Monterosso al Mare (Ligurian Sea) and Its Resilience Over a Decade(1998-2009). Environmental Management 50:598-606

Murray MG, Thompson WF (1980) Rapid isolation of high molecular weight plant DNA. Nucleic Acids Res 8:4321-4325

Murray MG, Ellison PJ, Watson A (1995) Effects of stripe rust on the wheat plant. Australasian Plant Path 24 (4):261-270

Nagamine T, Sekiwa, T, Yamaguchi E, Oozeki M, Kato T (2009) Relationship between quality parameters and SKCS hardness index in malting barley. Journal of the Institute of Brewing 115(4):292-295

Page RDM (1996) TREEVIEW: An application to display phylogenetic trees on personal computers. Computer Applications in the Biosciences 12:357-358.

Sluiter A, Hames B, Hyman D, Payne C, Ruiz R, Scarlata C, Sluiter J, Templeton D, Wolfe J (2008). Determination of Total Solids in Biomass and Total Dissolved Solids in Liquid Process Samples. National Renewable Research Technical Report NREL/TP-510-42621

Sluiter A, Hames B, Ruiz R, Scarlata C, Sluiter J, Templeton D (2008a) Determination of ash in biomass. National Renewable Research Laboratory Technical Report NREL/TP-510-42622

UNIDO, United Nations Industrial Development Organization, 2010. The Secretary-General's Advisory Group on Energy and Climate Change (AGECC) Energy for Sustainable Future - Summary report and recommendations.

https://sustainabledevelopment.un.org/index.php?page=view\&type $=400 \& n r=140 \&$ menu $=35$ 